\title{
Differences in photosynthetic marine biofilms between sheltered and moderately exposed rocky shores
}

\author{
R. C. Thompson ${ }^{1,3, *}$, P. S. Moschella ${ }^{2,4}$, S. R. Jenkins ${ }^{2,3}$, T. A. Norton ${ }^{3}$, \\ S. J. Hawkins ${ }^{2,3,4}$ \\ ${ }^{1}$ Marine Biology and Ecology Research Centre, School of Biological Sciences, University of Plymouth, Plymouth PL4 8AA, UK \\ ${ }^{2}$ Marine Biological Association, Plymouth PL1 2PB, UK \\ ${ }^{3}$ Port Erin Marine Laboratory, University of Liverpool, Port Erin, Isle of Man IM9 6JA, UK \\ ${ }^{4}$ School of Biological Sciences, University of Southampton, Southampton SO16 7PX, UK
}

\begin{abstract}
Photosynthetic microbial biofilms are an important functional component of rocky intertidal habitats worldwide. The abundance of organisms within these films varies both seasonally and according to vertical emersion gradients. However, the effects of horizontal gradients of wave exposure, which have a key influence on macrobiotic assemblages, have received little attention. Here, we examine the relative importance of exposure to wave action, tidal elevation and season on intertidal microbial assemblages. The abundance of micro-organisms was quantified using counts of major functional groups and total photosynthetic biomass, assessed using extracted chlorophyll. These data were compared between 2 moderately exposed and 2 sheltered shores on replicated sampling dates during summer and winter at 3 tidal levels. Diatoms were approximately 6 times more abundant on moderately exposed shores than on sheltered shores. This pattern was consistent between sites and seasons. The percentage cover of cyanobacteria and total photosynthetic biomass was also typically greater on exposed shores. Seasonal variations were also apparent with a trend of greater photosynthetic microbial biomass during the winter than during the summer. Photosynthetic biomass and, to a lesser extent, the abundance of cyanobacteria were greater on the lower shore than on the upper shore. The possible causes of the differences in microbial assemblages between sheltered and exposed shores are discussed. We suggest that indirect effects of habitat amelioration from macroalgal canopy and grazer density, which also covary along the wave exposure gradient, may be more important than the direct effects of wave action itself.
\end{abstract}

KEY WORDS: Biofilm · Microphytobenthos - Diatom - Cyanobacteria $\cdot$ Limpet · Patella vulgata Biological interactions · Ascophyllum nodosum

Resale or republication not permitted without written consent of the publisher

\section{INTRODUCTION}

Biofilms consisting of mucus, bacteria and microalgae form on any hard surface immersed in water (Wahl 1989), and are a key, but frequently overlooked, functional component of the benthos on rocky shores worldwide (e.g. Castenholz 1963, Underwood 1984b, Hill \& Hawkins 1991, Bustamante et al. 1995, Jenkins et al. 2001). Biofilms are important for habitat selection by settling larvae (e.g. Crisp 1974, Thompson et al.
1998) and also provide the main food resource for a variety of grazers (Steneck \& Watling 1982, Underwood 1984a, Hawkins et al. 1989, Hill \& Hawkins 1991, Sommer 1999, Jenkins et al. 2001).

The abundance of microorganisms within biofilm communities on moderately exposed rocky shores is regulated by physico-chemical factors such as emersion stress and nutrient availability, and by biological factors such as grazing. Microphagous grazers are reasonably unselective, removing diatoms, cyanobacteria and 
macroalgal germlings (Steneck \& Watling 1982). Exclusion of grazers directly results in microbial and then macroalgal proliferation (Southward 1964, Hawkins \& Hartnoll 1983, Farrell 1988, Mak \& Williams 1999, Thompson et al. 2000). Shading to reduce insolation stress has also been shown to increase microbial abundance. Elevated nutrient levels can enhance microbial biomass on sedimentary shores (Decho 2000); in contrast, experimentally increasing nutrient availability on rocky shores appears to have little effect (Thompson et al. 2004). Microbiota within these films also show seasonal patterns of abundance, which appear to be reasonably consistent in temperate areas world wide; increasing during the winter and then declining with the onset of summer (Cubit 1984, Underwood 1984b, Hill \& Hawkins 1991, Jenkins et al. 2001). These effects can be amplified by tidal elevation, with greater seasonal variation on the upper shore, where emersion stresses are greater (Aleem 1950, Castenholz 1963, Thompson et al. 2004 in the N. hemisphere, but see Underwood 1984b for an opposite trend in Australia). Recent work on moderately exposed shores in the NE Atlantic has shown that microbial abundance is regulated by the interactive effects of seasonal variations in emersion stresses (principally insolation), combined with increased grazing intensity during the summer (Thompson et al. 2004).

The majority of research on marine biofilms has taken place on moderately exposed rocky shores (e.g. Castenholz 1961, Hill \& Hawkins 1991, Jenkins et al. 2001) and sheltered shores have received much less attention (but see Underwood 1984b, Jenkins \& Hartnoll 2001). Physical conditions and major biological interactions are markedly different on sheltered shores to those at more exposed sites (Ballantine 1961, Lewis 1964, Stephenson \& Stephenson 1972, Robles \& Desharnais 2002). Moderately exposed shores in northern Europe are typically covered by a mosaic of patches of barnacles, bare rock and algae together with grazing molluscs, whereas sheltered shores are generally covered by dense uninterrupted stands of macroalgal canopy (mainly Ascophyllum nodosum L. Le Jolis), beneath which the substratum is usually covered by patches of turf-forming algae and areas of open rock grazed by limpets and littorinids (Lewis 1964, Jenkins et al. 1999).

The overall aim of this study was to compare photosynthetic microbial communities at different tidal levels between replicate moderately exposed and sheltered shores and to show how the patterns observed varied between summer and winter. This was achieved using a combination of direct counts of cells on rock surfaces chipped from the shore and examined using scanning electron microscopy (SEM), together with extracted chlorophyll, as an index of total photosynthetic biomass.

\section{MATERIALS AND METHODS}

Two moderately exposed shores: Port St. Mary and Derbyhaven and 2 sheltered shores: Langness and Castletown were examined, all of which were on the Isle of Man, UK $\left(4^{\circ} 44^{\prime} \mathrm{W}, 54^{\circ} 4^{\prime} \mathrm{N}\right)$. Thomas exposure scale values (Thomas 1986), based on monthly averages for the period 1989 to 1993 inclusive, gave a clear separation between the exposed and sheltered sites selected $($ Port St. Mary $=3.45$, Derbyhaven $=2.34$, Langness $=1.3$, Castletown $=1.3$ ). Wave heights across the vertical profile of these shores rarely exceeded $0.5 \mathrm{~m}$ at sheltered sites, but regularly exceeded $2.0 \mathrm{~m}$ at exposed sites (S. J. Hawkins, R. C. Thompson \& S. R. Jenkins pers. obs., based on 30 years of research at these locations). Moderately exposed shores had a characteristic mosaic of fucoid algae, barnacles and limpets (mainly Patella vulgata L.), interspersed with large areas of open rock (Southward 1953, Hartnoll \& Hawkins 1985). Sheltered shores were dominated by a dense macroalgal canopy of Ascophyllum nodosum (L.) Le Jolis, beneath which the substratum was covered by red algal turf and small areas of rock grazed by limpets (mainly $P$. vulgata L.) together with some littorinids (mainly Littorina obtusata see Jenkins et al. 1999).

The abundance of photosynthetic microbiota was monitored at each site on randomly selected occasions, twice during the summers and twice during the winters of 1993 and 1994 (Fig. 1). On each occasion, rock chips were collected from each of 3 tidal levels: lower (mean low-water neaps), mid-tide and upper (mean high-water neaps). On moderately exposed shores, microbial abundance is enhanced in areas beneath macroalgal canopy compared to areas of adjacent open rock (Thompson et al. 2004). Therefore, to avoid potential confounding effects, all samples were collected from rock surfaces that were beneath macroalgal canopy, but were bereft of other macrobiota or encrusting algae. At each tidal level, these areas of rock surface were selected at random from within $4 \mathrm{~m} \times 10 \mathrm{~m}$ plots parallel to the sea. Rock chips were removed from each area using a hammer and chisel. Care was taken to ensure that samples were taken from positions separated by at least $30 \mathrm{~cm}$ to ensure independence.

On each sampling occasion, at each location, photosynthetic microbial biomass was quantified from 18 rock chips, each $\sim 2 \mathrm{~cm} \times 2 \mathrm{~cm}$, by extracting chlorophyll $a$ in methanol. This method gives a reliable index of biomass without the need to also quantify other photosynthetic pigments (Thompson et al. 1999). In addition, the abundance of organisms was determined using SEM to view the surface of six $1 \mathrm{~cm}$ $\times 1 \mathrm{~cm}$ chips. Both these approaches have been ex- 


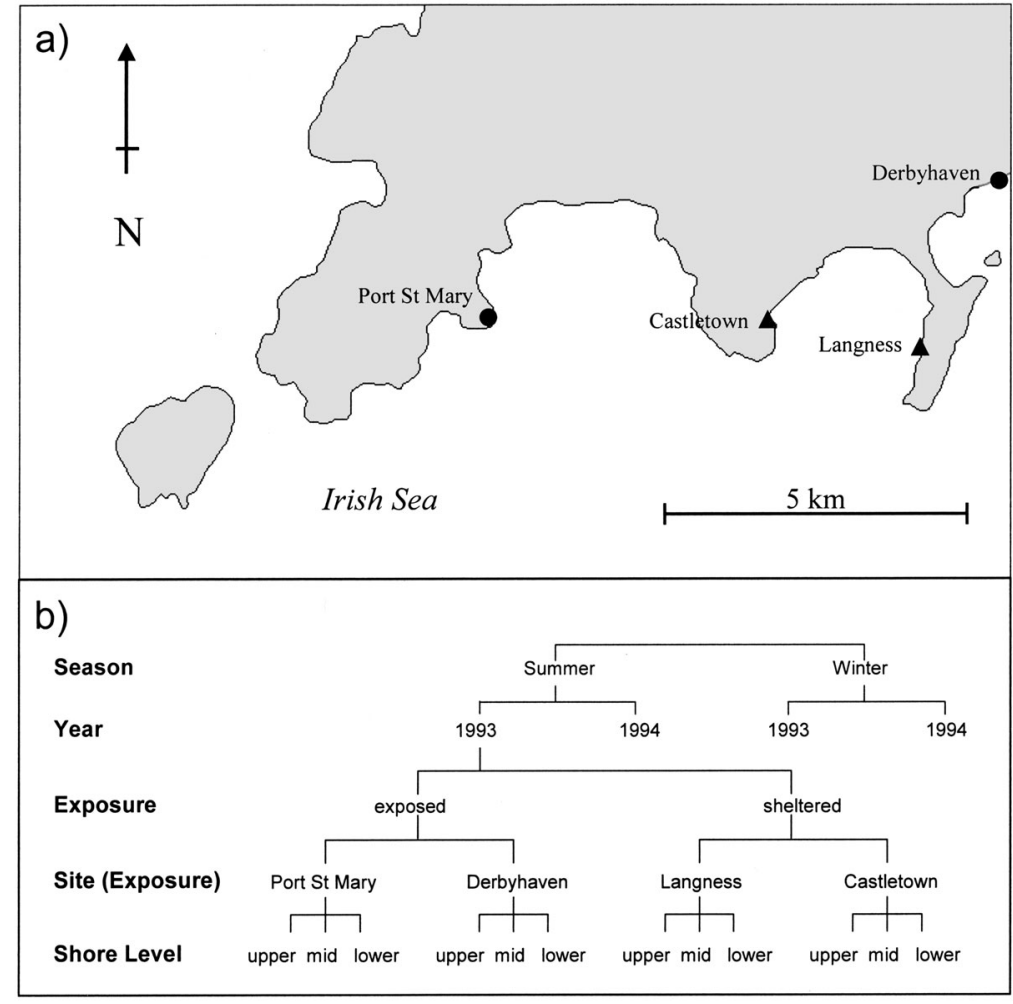

Fig. 1. (a) Map of study sites on the Isle of Man, UK. •: moderately exposed shores; $\mathbf{\Delta}$ : sheltered shores. (b) Schematic diagram illustrating the experimental design used for temporal and spatial comparisons at sites of differing exposure to wave action. The sampling scheme with respect to Exposure, Site (Exposure) and Shore Level (shown) was repeated on each of the 4 sampling occasions shown

tensively used to study biofilms on rocky shores. SEM can be used to record the relative abundance of organisms (Hill \& Hawkins 1990), but cannot penetrate beneath the surface layer of a biofilm. Hence, SEM is likely to result in an underestimate of abundance for thicker films, but will give a reasonable representation of abundance on relatively thin films, such as those found on heavily grazed rocky shores (e.g. film thickness 20 to $25 \mu \mathrm{m}$, Norton et al. 1998). Conversely, extracted chlorophyll a gives a good indication of total photosynthetic biomass throughout a 3dimensional biofilm and has been shown to give reliable and repeatable correlations with the number of microalgal cells present (Underwood 1984b). However, unlike SEM, this approach cannot give any information on the relative abundance of different organisms within the film. Hence, a combination of SEM and chlorophyll extraction was adopted (for a full discussion of these methods, see Underwood 1984b, Hill \& Hawkins 1990, Norton et al. 1998 and Thompson et al. 1999). Rock chips for SEM were fixed in glutaraldehyde (5\% in seawater) and examined at $480 \times$ magnification. Formal comparisons were made using averages from counts in 6 randomly positioned photographs on the surface of each sample (Hill \& Hawkins 1990). Previous work has shown that photosynthetic biofilms at these sites are dominated by diatoms (predominantly Achnanthes spp.) and cyanobacteria (predominantly Lyngbya spp. and Oscillatoria spp., see Thompson et al. 2004), and so formal comparisons were restricted to these 2 groupings. The original experimental design was to compare the abundance of photosynthetic microbiota beneath fucoid canopy at each tidal level, but Fucus cover declined substantially during the sampling period and by 1994. F. vesiculosus was absent from the mid shore at Port St. Mary. Hence, formal statistical comparisons of microbiota were only possible between the upper and lower shore. However, data from all 3 tidal levels are presented graphically to allow qualitative comparisons for periods where macroalgal canopy was present.

The abundance of macrobiota is known to vary along exposure gradients (Lewis 1964, Stephenson \& Stephenson 1972). Of particular relevance here, were variations in the abundance of grazers, variations in the amount of biofilm-coated substratum on which grazers can feed (i.e. the combined surface area of rock, crustose coralline algae and barnacles) and the extent of macroalgal canopy. These variables were quantified using 18 randomly positioned $50 \mathrm{~cm} \times 50 \mathrm{~cm}$ quadrats at each shore level at each site.

Formal comparisons were made using mixed-model analysis of variance (ANOVA) followed by post hoc Student Newman-Keuls (SNK) comparisons. For photosynthetic microbial biomass and the abundance of diatoms, a 5-factor ANOVA was used, where 'Exposure' had 2 levels (moderately exposed and sheltered), 'Season' had 2 levels (summer and winter) and 'Shore Level' had 2 levels (upper and lower). These were treated as fixed orthogonal factors, while 'Shore' (nested within exposure) and 'Year' were random factors, each having 2 levels. A small number of values for chlorophyll a were below acceptable limits of detection for the spectrophotometer. These were not used and therefore in order to balance the data for ANOVA, samples were removed at random from each 'Shore Level', 'Site' and 'Year' grouping, giving a value of $\mathrm{n}=17$ for our statistical analyses rather than $n=18$ as collected. Data were transformed where appropriate to achieve homogeneity of variance. Some data could not be corrected for hetero- 


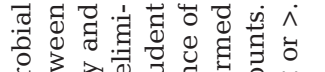

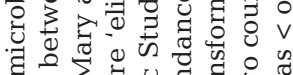

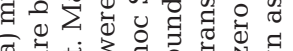

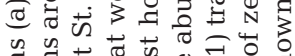
敢记

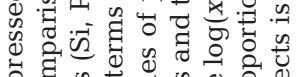

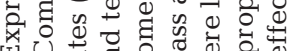

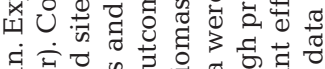

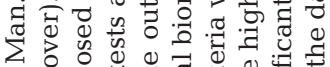

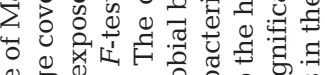

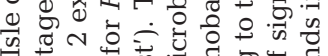

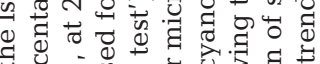

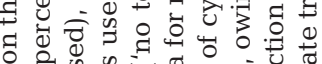

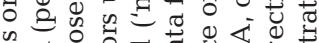
o 0 .

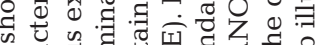

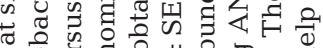

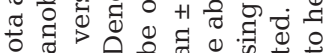
त्वे के

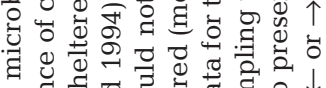

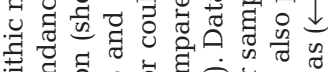
青告 के

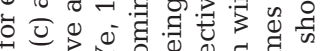

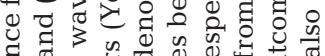

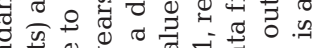

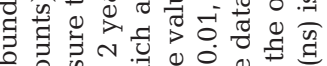
。

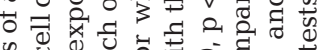
马 ब

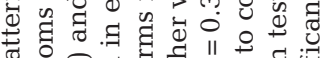

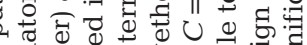
考 击

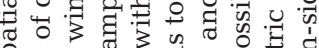

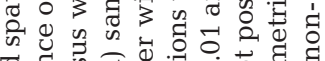

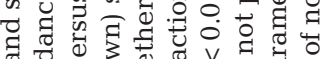

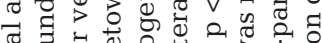

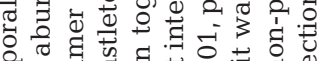

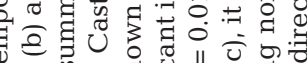

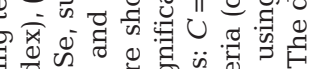
害 幽 㶽

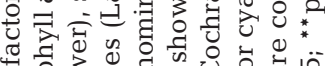

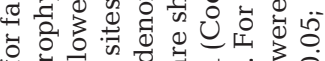

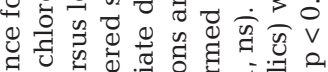
。 व

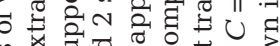

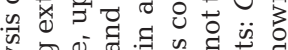

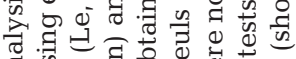

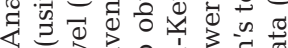
-

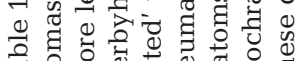

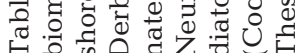

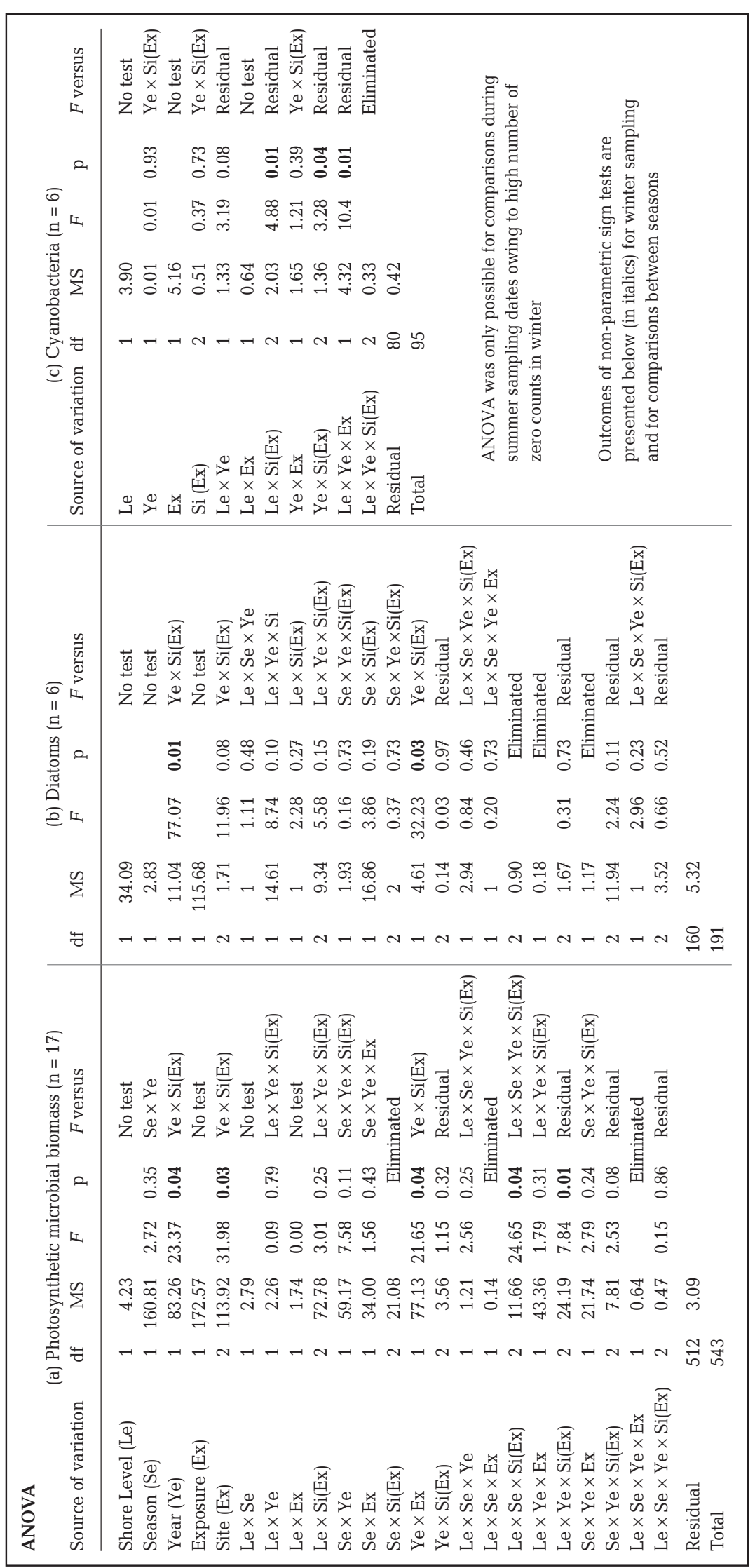




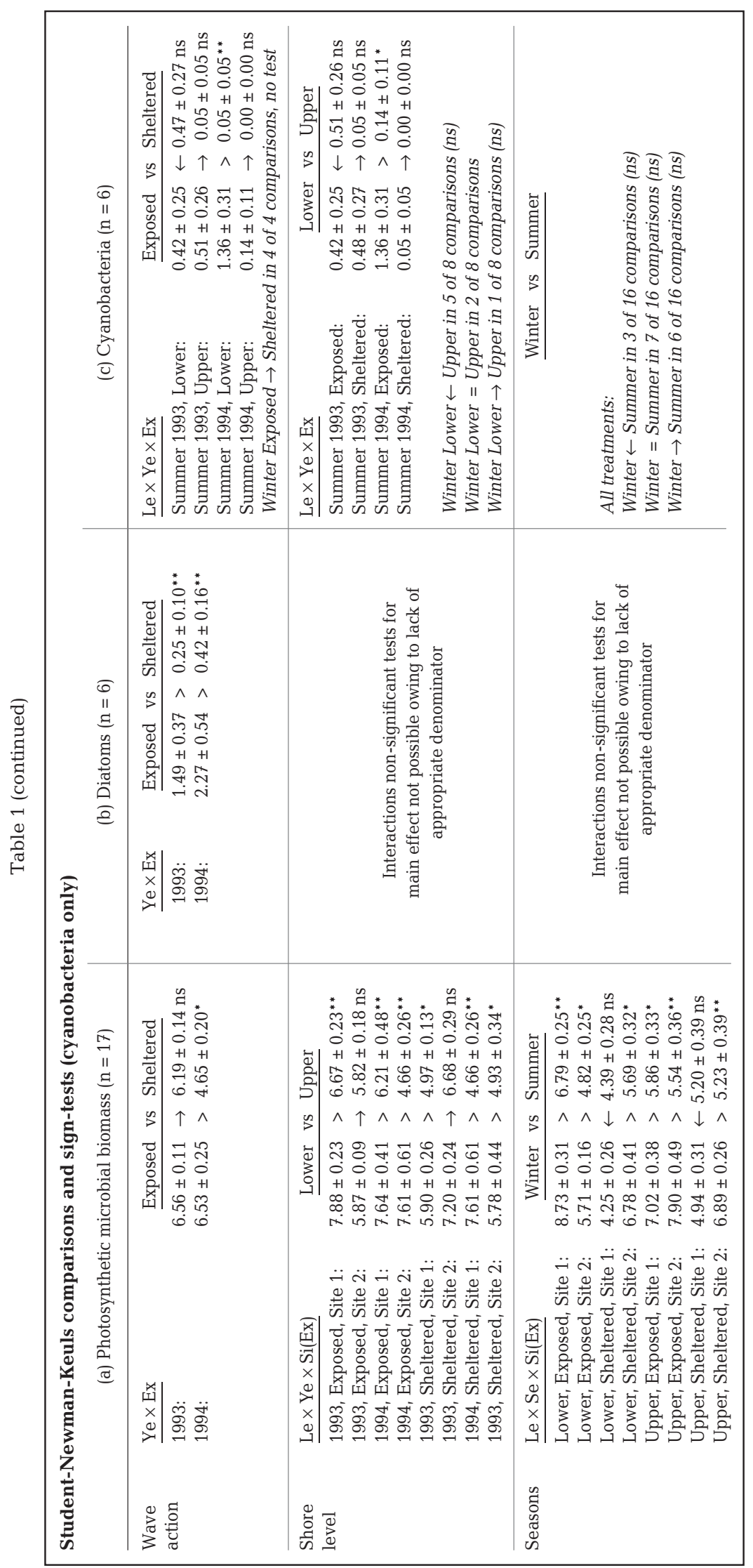

scedasticity; in these cases, untransformed data were analysed, as ANOVA is considered to be reasonably robust to lack of homogeneity with balanced designs of large samples sizes as used here (Underwood 1997). In mixed models such as this, with randomly selected sampling dates and sites, it is inevitable that some main effects and their interactions cannot be directly tested because of the lack of a denominator for F-tests. In these cases, terms were eliminated where appropriate so that denominators could be obtained. To minimise the risk of Type II errors, this procedure was only applied where the associated p-values were greater than 0.25 (Underwood 1997). Cyanobacteria were virtually absent during winter sampling and hence, because of the high proportion of zero counts, ANOVA comparisons between sheltered and exposed shores were restricted to summer sampling dates using a 4-factor ANOVA (as above but without 'Season'). Comparisons within the winter sampling period (between shores of differing exposure and between tidal levels) and between the summer and winter sampling occasions (effect of season) were, however, made using non-parametric sign tests.

\section{RESULTS}

Photosynthetic microbial standing stock (chlorophyll a) differed between shores, shore levels and seasons. The effects of 'Exposure' to wave action interacted with 'Year' (Ye $\times$ Ex, Table 1a), showing a consistent trend of greater standing stock on exposed shores during both 1993 and 1994, but with a significant effect in 1994 only. The influence of wave exposure was also apparent from qualitative comparisons of the global means across all 3 tidal levels and was especially evident during winter sampling (sheltered shores, $\mathrm{n}=12$ sets of 17 rock chips $=5.54 \pm 0.45 \mu \mathrm{g} \mathrm{l}^{-1}$; exposed shores, $\mathrm{n}=11$ sets of 17 rock chips $=7.32 \pm 0.41 \mu \mathrm{g} \mathrm{l}^{-1}$; global means \pm SE, see Fig. 2a).

The abundance of diatoms (predominantly Achnanthes spp.) varied considerably between shores of differing exposure, with around 6 times greater abundance on moderately exposed shores 
Table 2. Density of limpets and other grazers (on sheltered shores, mostly Littorina obtusata, Gibbula umbilicalis and L. littorea together with some $L$. saxatalis, L. nigrolineata; on moderately exposed shores, some L. obtusata and L. saxatalis), and the area of substratum available for grazing (rock, crustose coralline algae and barnacles combined) on sheltered and moderately exposed rocky shores on the Isle of Man. For limpets, the density per unit area of substratum available for grazing is shown. The extent of macroalgal canopy cover is also shown. Note that since macroalgae grow as a canopy over the substratum, the total combined area of canopy and the area of substratum available for grazing can exceed $100 \%$ (values are means $\pm \mathrm{SE}, \mathrm{n}=18$ )

\begin{tabular}{|lccccc|}
\hline & $\begin{array}{c}\text { Limpet density } \\
\mathrm{m}^{-2} \text { of shore }\end{array}$ & $\begin{array}{c}\text { Density of other } \\
\text { grazers } \mathrm{m}^{-2}\end{array}$ & $\begin{array}{c}\text { Area shown substratum } \\
\text { available for grazing }(\%)\end{array}$ & $\begin{array}{c}\text { Limpet density } \\
\mathrm{m}^{-2} \text { available } \\
\text { for grazing }\end{array}$ & $\begin{array}{c}\text { Macroalgal } \\
\text { cover }(\%)\end{array}$ \\
\hline $\begin{array}{l}\text { Moderately exposed shores } \\
\text { Port St. Mary }\end{array}$ & $19.78 \pm 3.83$ & $0.00 \pm 0.00$ & $86.70 \pm 2.25$ & $22.83 \pm 4.42$ & $10.80 \pm 3.23$ \\
Derbyhaven & $24.15 \pm 9.56$ & $0.44 \pm 0.17$ & $88.96 \pm 1.78$ & $28.73 \pm 12.84$ & $15.26 \pm 3.39$ \\
Sheltered shores & $6.50 \pm 2.36$ & $19.11 \pm 2.23$ & $35.64 \pm 3.90$ & $17.07 \pm 5.32$ \\
Langness & $6.81 \pm 1.87$ & $23.04 \pm 2.44$ & $51.24 \pm 4.22$ & $18.30 \pm 10.38$ & $92.50 \pm 2.15$ \\
Castletown & & & & \\
\hline
\end{tabular}

than on sheltered shores (Fig. 2b). This pattern was consistent in both 1993 and 1994 irrespective of season, shore level or site nested within exposure, but had a greater magnitude of effect in 1994 (Ye $\times$ Ex, Table 1b). There were no significant interactive effects with season or shore level, but it was not possible to test for main effects of 'Shore Level' (Le) or 'Season' (Se) as denominators for appropriate $F$-tests could not be obtained by elimination. However, mean squares for both SE and LE indicated that these factors explained a small proportion of the variance compared to wave exposure.

Visual inspection of SEM data for the abundance of cyanobacteria (predominantly Lyngbya spp. and Oscillatoria spp.) showed a marked seasonal effect; cyanobacteria were virtually absent from sheltered shores during the winter and were scarce on moderately exposed shores (Fig. 2c). Hence, parametric analysis of the entire data set was not possible, owing to the high proportion of zero counts during winter. Seasonal trends were examined using a non-parametric sign-test. However, only 6 out of 16 comparisons showed a greater abundance of cyanobacteria during summer and this was not significant (Table 1c). Cyanobacteria were generally more abundant on exposed shores than on sheltered shores (Fig. 2c). Parametric analysis on summer data, which was amenable to ANOVA, indicated that abundance varied between shore levels and sampling dates $($ Le $\times$ Ye $\times$ Ex interaction, Table 1c). There was a general trend of greater abundance on moderately exposed shores in 3 out of 4 post hoc SNK comparisons, but the effect was only significant on the lower shore during 1994. A similar pattern of greater abundance on moderately exposed shores was also apparent during winter sampling, with exposed shores having a greater percentage cover of cyanobacteria than sheltered shores in 4 out of 4 comparisons. This did not provide sufficient comparisons to conduct a sign test (Table 1c). ANOVA on summer data showed a trend of greater abundance on the lower shore than the upper shore (3 out of 4 SNK comparisons, Table 1c), but this effect was only significant on moderately exposed shores in 1994. For data collected during the winter, cyanobacteria were more abundant on the upper shore than on the lower shore in 5 out of 8 comparisons, but this trend was not significant when examined using a sign test.

Limpets were more abundant on moderately exposed shores than on sheltered shores (Table 2). However, when taking into consideration the area of substratum available for grazing per limpet, this effect became less evident as the area available for grazing on sheltered shores was around half of that on moderately exposed shores. In addition, sheltered shores supported a greater diversity and abundance of other grazing species (mostly Littorina obtusata, Gibbula umbilicalis and L. littorea, together with some L. saxatalis and L. nigrolineata) than did exposed shores (some L. obtusata and L. saxatalis, Table 2). Macroalgal canopy was far more extensive on sheltered shores, where it covered over $90 \%$ of the shore, than on moderately exposed shores which had only 10 to $15 \%$ cover.

\section{DISCUSSION}

One of the main findings of our work is the pattern of greater microbial abundance, in terms of both cell counts and total photosynthetic biomass, on moderately exposed shores compared to sheltered shores. This was especially clear for diatoms, where the pattern was consistent across sampling dates and sites, and therefore probably indicates a general effect that can be extrapolated to similar shores elsewhere. Similar trends were evident for microbial biomass and cyanobacteria. 

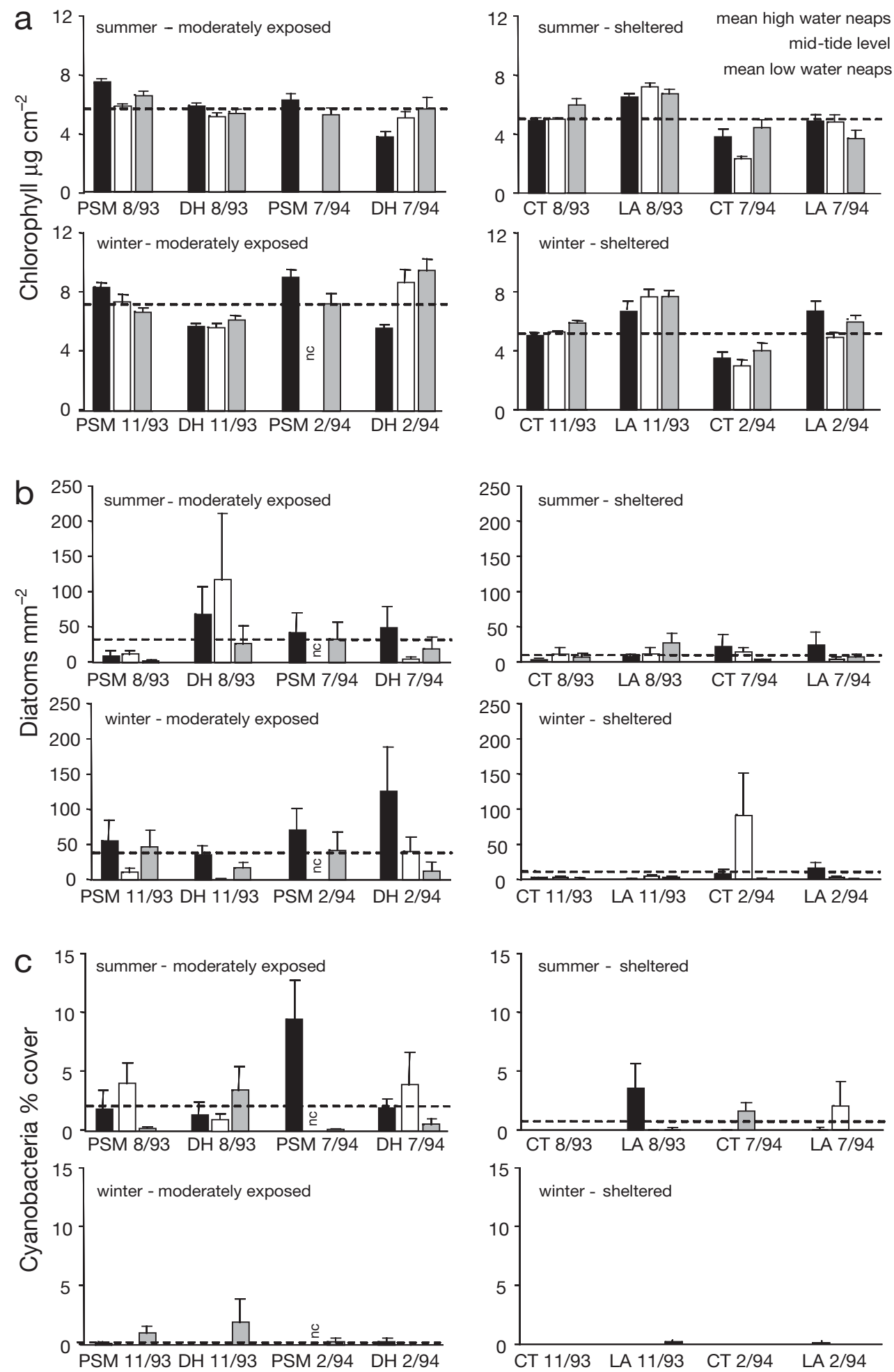

Fig. 2. Abundance of epilithic microbiota on rocky shores on the Isle of Man expressed as (a) microbial biomass (using extracted chlorophyll as an index), (b) abundance of diatoms (cell counts) and (c) abundance of cyanobacteria (percentage cover). Data are shown for 3 tidal heights at each of 2 moderately exposed shores: Port St. Mary (PSM) and Derbyhaven (DH), and 2 sheltered shores Castletown (CT) and Langness (LA) sampled on 2 dates (mo/yr) during summer and 2 dates during winter. Dashed lines indicate global mean values for each graph to allow qualitative comparisons between exposure levels and seasons (values are means \pm SE). nc: no canopy, as a consequence of a natural decline in macroalgal abundance at Port St. Mary during the course of the study (see 'Materials and methods') 
However, the strength of these effects was much weaker for cyanobacteria than with either microbial biomass or the abundance of diatoms. Patterns of abundance for both cyanobacteria and microbial biomass were also less consistent in time and space than for diatoms.

The causes of these patterns are not clear. Macroalgae typically show the opposite trend, with abundance decreasing as a consequence of both increased physical damage from wave action and increased grazing intensity at more exposed sites (Southward 1964, Hawkins \& Hartnoll 1983), and this pattern was true of the sites examined here (Table 2). For marine microbiota, there is some evidence of standing stock increasing with water movement. For example, some species of planktonic surf diatoms exploit regions of high turbulence on exposed sandy shorelines (Schaefer \& Lewin 1984, Campbell 1996). In freshwater streams and rivers, epilithic microbiota are also more abundant in regions of higher flow (Sabater \& Roca 1990). Furthermore, there is evidence that fast flow conditions during floods may enhance biofilm production (Lock 1993). Similarly, elevated water flow has been shown to enhance growth of subtidal macroalgae (see Hurd 2000 for review). On rocky shores, diatoms such as Achnanthes, which are strongly attached to the substratum, may also benefit from increased flow in waveexposed locations. The direct effects of water flow, in increasing nutrient supply and the increased potential for 'in-water' photosynthetic activity, could, therefore, explain the patterns of microbial abundance observed in the present study.

The effects of molluscan grazers in regulating macroalgal growth are well recognised on shores in the north-east Atlantic (e.g. Southward 1964, Hawkins \& Hartnoll 1983). There is also clear evidence that these molluscs, particularly limpets, have a strong effect in controlling microbial biomass on rocky shores (Hill \& Hawkins 1991, Thompson et al. 2000, Jenkins et al. 2001, Thompson et al. 2004). For example, Thompson et al. (2004) demonstrated a $20 \%$ increase in microbial biomass within 2 wk following experimental reduction of limpet density. Since the density of patellid limpets, which are the principal grazer on the shores examined here (see Hartnoll \& Hawkins 1985), was greater per unit area of shore on moderately exposed sites than on sheltered sites, it seemed that differences in grazing intensity could not explain the patterns of microbial biomass observed. However, since limpets feed principally from microalgae on the surface of bare rock, crustose coralline algae (predominantly Phymatolithon lenormandii and P. purpureum) and barnacles, the actual density of these grazers per unit area of grazeable substrate was relatively similar between sheltered and exposed shores (Table 2). Moreover, when considering the mid-shore alone,
Jenkins et al. (1999), reported that limpet density per unit area of grazeable substratum was up to 3 times greater on sheltered shores than on moderately exposed shores. The reduced area available for feeding, combined with the greater diversity and abundance of other grazing species on sheltered shores (Table 2) must, therefore, be taken into account when considering the possible causes of variation in microbial abundance between sheltered and exposed shores.

In addition to grazing, changes in the density of macroalgal canopy cover along the wave exposure gradient may also influence microbial biomass. Jenkins \& Hartnoll (2001) compared microbial standing stock between sheltered and exposed shores amongst plots that had been manipulated to have identical grazer density, but which had canopy present on sheltered shores and absent on moderately exposed shores. In these treatments, microbial biomass was significantly greater on sheltered shores (beneath canopy) than on exposed shores. However, the opposite trend was evident here; in comparisons between areas with similar macroalgal cover (all sampling was from areas beneath macroalgal canopy, see 'Materials and methods') and broadly similar grazing intensity, microbial abundance was less on sheltered shores. Hence, it would appear that patterns of microbial abundance can be reversed according to the relative extent of macroalgal canopy cover. Therefore, the patterns of microbial abundance along the wave exposure gradients described here are most likely driven by a combination of direct effects of increased turbulence on wave-exposed shores together with indirect effects of changes in macroalgal canopy cover and grazer density (Jenkins et al. 1999, Thompson et al. 2004). However, manipulative experiments accompanied by direct measures of physical and biological conditions along both wave exposure and emersion gradients would be required to confirm the relative importance of these factors.

The statistical significance of seasonal effects could not be directly tested for either photosynthetic microbial biomass or for the abundance of diatoms. However, previous work on the Isle of Man and other moderately exposed locations has shown that, typically, both decline markedly during the summer (Aleem 1950, Castenholz 1963, Hill \& Hawkins 1991, Thompson et al. 2004) and a similar trend is evident in the data presented here (Fig. 2a,b) . For cyanobacteria, a different trend was evident with greatest abundance on moderately exposed shores irrespective of season, followed by lower abundance on sheltered shores during summer and a virtual absence on sheltered shores during the winter (Fig. 2c, Table 1c). These patterns broadly follow the prevailing light intensity 
and suggest that cyanobacteria may be light-limited on sheltered shores during the winter. Previous work on moderately exposed shores has indicated that seasonal patterns in the abundance of cyanobacteria differ between tidal levels, being maximal on the lower shore in summer and on the upper shore during the winter (Thompson et al. 2004). Hence, it appears that the abundance cyanobacteria in the intertidal may be regulated by the interactive effects of season, tidal elevation and the extent of macroalgal canopy cover. For example, high levels of insolation stress on the upper shore appear to reduce cyanobacterial abundance during summer, while low light levels in areas beneath macroalgal canopy also appear to reduce abundance on sheltered shores during winter. This observation could be important when assessing intertidal primary productivity in shaded areas of shoreline or at higher latitudes where light levels may be especially low during the winter. The effects of shore level on microbial biomass were reasonably consistent across sites and seasons, with a trend of greater abundance on the lower shore than on the upper shore. These results are consistent with previous research, which has shown that the abundance of photosynthetic microbiota can be greater on the upper shore than on the lower shore during the winter, while being reasonably stable on the lower shore throughout the year (Aleem 1950, Castenholz 1963, Thompson et al. 2004).

With respect to grazing intensity, the present study and that of Jenkins \& Hartnoll (2001) have demonstrated that estimates of limpet density are directly influenced by the amount of grazeable substrate and that this varies considerably between sheltered and exposed shores. This is an important observation, which would not be evident from sampling grazer abundance per total area of shore. Hence, when considering grazer/microalgal interactions, it is important to assess grazer density per unit area of habitat available for feeding, rather than simply per unit area of substratum. The causes of variations in grazer diversity and abundance along the wave exposure gradient are not clear, although they are likely to be the product of interactions among a number of physical and biological factors including supply of larvae, availability of nursery habitat such as rock pools, predation and food supply. Food availability, in terms of standing stock, was less on sheltered than on moderately exposed shores, yet sheltered shores seem to support similar (this study) and in some areas greater (e.g. Jenkins \& Hartnoll, 2001) densities of limpet grazers per area of grazeable substratum. At some locations, limpets on sheltered shores are known to graze on macroalgae (e.g. Strangford Lough: M. P. Davies, C. A. Maggs \& A. Johnson unpubl. data), possibly to subsidise shortages in microalgal resources. This was not apparent at the study sites examined here and an explanation for the greater diversity and abundance of molluscs on sheltered shores could be that physical conditions and food availability remain more consistent beneath dense macroalgal canopy, which is present on sheltered shores, than on moderately exposed shores, where macroalgae are more patchily distributed. Thermal and insolation stress are reduced on rock surfaces beneath macroalgal canopy (e.g. temperatures at low tide: open rock $=25.68 \pm 0.22^{\circ} \mathrm{C}$; beneath Fucus clump $=20.68 \pm 0.11$, mean \pm SE, P. Moore \& R. C. Thompson unpubl. data). Since the grazing intensity of limpets is positively correlated with temperature (Thompson et al. 2000), shading by macroalgae is likely to reduce grazing intensity on the substratum beneath. Indeed Jenkins \& Hawkins (2001) showed relatively consistent levels of limpet grazing activity on canopy-dominated sheltered shores compared to strongly seasonal effects on exposed shores. Shading has also been shown to increase microalgal standing stock by up to $20 \%$ compared to areas of open rock, and this may explain why microbial standing stock is greater on rock surfaces beneath Fucus than on open rock (Thompson et al. 2004). Hence, it appears that macroalgal canopy could effectively stabilise environmental conditions on sheltered shores, compared to those experienced on exposed shores, thereby moderating the stresses that can reduce microalgal growth and generating a more consistent physiological requirement for food from the grazers present. This will influence both the supply of and the demand for resources and could explain how sheltered shores can support a higher diversity and, in some locations, a greater abundance of grazing molluscs (per unit area of grazeable substratum) than more exposed shores, despite the actual standing stock of microbial food resources being less than on more exposed shores. Manipulative experiments would be required to confirm these suggestions. However, the observation that on moderately exposed shores, where the distribution of macroalgal canopy is quite patchy, Patella vulgata chooses to aggregate beneath macroalgae (Hawkins \& Hartnoll 1983), provides some additional support for this hypothesis.

Our study emphasises the importance of physical and biological interactions along wave exposure gradients. Wave exposure is known to directly influence macrobiota, causing physical damage (Dayton 1971) and dislodgement (e.g. Trussell et al. 1993, Underwood 1998), but also enhances algal growth (e.g. Hurd 2000) or increases the supply of larvae (e.g. Steffani \& Branch 2003). Indirect effects of wave exposure have also been demonstrated in numerous studies as a consequence of changes in competitive ability (e.g. Steffani \& Branch 2003), grazing activity (e.g. Duggins et al. 2001) and predation (e.g. Menge et al. 1994, Robles \& Desharnais 
2002), and through modification of physical factors such as emersion stresses (e.g. Harley \& Helmuth 2003). These direct and indirect effects of wave action have a key role in regulating the structure of macrobiotic communities (Hawkins \& Hartnoll 1983, Menge et al. 1994, Nielsen 2001, Steffani \& Branch 2003). Here, we show that wave action also influences microbiota on rocky shores, probably as a consequence of both direct effects of flow and indirect effects of changes in macroalgal canopy cover and grazing intensity along the wave exposure gradient.

Acknowledgements. R.C.T. was funded by an NERC studentship (GT4/92/201/A, supervised by S.J.H. and T.A.N.). S.J.H. and R.C.T. were also funded by Leverhulme (F/180/AO) and NERC (GR9/3031) grants, S.J.H. and S.R.J. by an EC contract (MAS3-CT95-0012: EUROROCK) and by an NERC grant in aid to the Marine Biological Association. P.S.M. was funded by an EU Marie-Curie Fellowship. The authors would like to thank M. Tobin, C. Browne and K. Veltkamp for assistance with sample collection and analysis.

\section{LITERATURE CITED}

Aleem AA (1950) Distribution and ecology of British marine littoral diatoms. J Ecol 38:75-106

Ballantine WJ (1961) A biologically derived exposure scale for the comparative description of rocky shores. Field Stud 1: $1-19$

Bustamante RH, Branch GM, Eekhout S, Robertson B and 7 others (1995) Gradients of intertidal primary productivity around the coast of South Africa and their relationships with consumer biomass. Oecologia 102:189-201

Campbell EE (1996) The global distribution of surf diatom accumulations. Rev Chil Hist Nat 69:495-501

Castenholz RW (1961) The effect of grazing on marine littoral diatom populations. Ecology 42:783-794

Castenholz RW (1963) An experimental study of the vertical distribution of littoral marine diatoms. Limnol Oceanogr 8: 450-462

Crisp DJ (1974) Factors influencing the settlement of marine invertebrate larvae. In: Grant PT, Mackie AM (eds) Chemoreception in marine organisms. Academic Press, London, p 177-265

Cubit JD (1984) Herbivory and the seasonal abundance of algae on high intertidal rocky shore. Ecology 65: 1904-1917

Dayton PK (1971) Competition, disturbance and community organisation: the provision and subsequent utilisation of space in a rocky intertidal community. Ecol Monogr 41: 351-389

Decho AW (2000) Microbial biofilms in intertidal systems: an overview. Cont Shelf Res 20:1257-1273

Duggins D, Eckman JE, Siddon CE, Klinger T (2001) Interactive roles of mesograzers and current flow in survival of kelps. Mar Ecol Prog Ser 223:143-155

Farrell TM (1988) Community stability: effects of limpet removal and reintroduction in a rocky intertidal community. Oecologia 75:190-197

Harley CDG, Helmuth BST (2003) Local- and regional-scale effects of wave exposure, thermal stress, and absolute versus effective shore level on patterns of intertidal zonation. Limnol Oceanogr 48:1498-1508
Hartnoll RG, Hawkins SJ (1985) Patchiness and fluctuations on moderately exposed rocky shores. Ophelia 24:53-64

Hawkins SJ, Hartnoll RG (1983) Grazing of intertidal algae by marine invertebrates. Oceanogr Mar Biol Annu Rev 21: 195-285

Hawkins SJ, Watson DC, Hill AS, Harding SP, Kyriakides MA, Hutchinson S, Norton TA (1989) A comparison of feeding mechanisms in microphagous, herbivorous, intertidal, prosobranchs in relation to resource partitioning. J Molluscan Stud 55:151-165

Hill AS, Hawkins SJ (1990) An investigation of methods for sampling microbial films on rocky shores. J Mar Biol Assoc UK 70:77-88

Hill AS, Hawkins SJ (1991) Seasonal and spatial variation of epilithic microalgae distribution and abundance and its ingestion by Patella vulgata on a moderately exposed rocky shore. J Mar Biol Assoc UK 71:403-423

Hurd CL (2000) Water motion, marine macroalgal physiology, and production. J Phycol 36:453-472

Jenkins SR, Hartnoll RG (2001) Food supply, grazing activity and growth rate in the limpet Patella vulgata L.: a comparison between exposed and sheltered shores. J Exp Mar Biol Ecol 258:123-139

Jenkins SR, Hawkins SJ, Norton TA (1999) Direct and indirect effects of a macroalgal canopy and limpet grazing in structuring a sheltered inter-tidal community. Mar Ecol Prog Ser 188:81-92

Jenkins SR, Arenas F, Arrontes J, Bussell J and 10 others (2001) European-scale analysis of seasonal variability in limpet grazing activity and microalgal abundance. Mar Ecol Prog Ser 211:193-203

Lewis JR (1964) The ecology of rocky shores. English Universities Press, London

Lock MA (1993) Attached microbial communities in rivers. In: Ford TA (ed) Aquatic microbiology. Blackwell Scientific Publications, Oxford, p 113-138

Mak YM, Williams GA (1999) Littorinids control high intertidal biofilm abundance on tropical, Hong Kong rocky shores. J Exp Mar Biol Ecol 233:81-94

Menge BA, Berlow EL, Blanchette CA, Navarrete SA, Yamada SB (1994) The keystone species concept-variation in interaction strength in a rocky intertidal habitat. Ecol Monogr 64:249-286

Nielsen KJ (2001) Bottom-up and top-down forces in tide pools: test of a food chain model in an intertidal community. Ecol Monogr 71:187-217

Norton TA, Thompson RC, Pope J, Veltkamp CJ, Banks B, Howard CV, Hawkins SJ (1998) Using confocal laser scanning microscopy, scanning electron microscopy and phase contrast light microscopy to examine marine biofilms. Aquat Microb Ecol 16:199-204

Robles C, Desharnais R (2002) History and current development of a paradigm of predation in rocky intertidal communities. Ecology 83:1521-1536

Sabater S, Roca JR (1990) Some factors affecting distribution of diatom assemblages in Pyrenean Springs. Freshw Biol 24:493-507

Schaefer CT, Lewin J (1984) Persistent blooms of surf diatoms along the pacific coast, USA .4. Diatom productivity and its relation to standing stock. Mar Biol 83:205-217

Sommer U (1999) The susceptibility of benthic microalgae to periwinkle (Littorina littorea, Gastropoda) grazing in laboratory experiments. Aquat Bot 63:11-21

Southward AJ (1953) The ecology of some rocky shores in the south of the Isle of Man. Proc Trans Liverpool Biol Soc 59: $1-50$

Southward AJ (1964) Limpet grazing and the control of 
vegetation on rocky shores. In: Crisp DJ (ed) Grazing in terrestrial and marine environments. Blackwell Scientific Publications, Oxford, p 265-273

Steffani CN, Branch GM (2003) Temporal changes in an interaction between an indigenous limpet Scutellastra argenvillei and an alien mussel Mytilus galloprovincialis: effects of wave exposure. Afr J Mar Sci 25:213-229

Steneck RS, Watling L (1982) Feeding capabilities and limitation of herbivorous molluscs: a functional group approach. Mar Biol 68:299-319

Stephenson T, Stephenson A (1972) Life between the tidemarks on rocky shores. Freeman, San Francisco, CA

Thomas MLH (1986) A physically derived exposure index for marine shorelines. Ophelia 25:1-13

Thompson RC, Hawkins SJ, Norton TA (1998) The influence of epilithic microbial films on the settlement of Semibalanus balanoides cyprids - a comparison between laboratory and field experiments. Hydrobiologia 375/376:203-216

Thompson RC, Tobin ML, Hawkins SJ, Norton TA (1999) Problems in extraction and spectrophotometric determination of chlorophyll from epilithic microbial biofilms: towards a standard method. J Mar Biol Assoc UK 79: $551-558$

Thompson RC, Roberts MF, Norton TA, Hawkins SJ (2000) Feast or famine for intertidal grazing molluscs: a mismatch between seasonal variations in grazing intensity

Editorial responsibility: Otto Kinne (Editor-in-Chief), Oldendorf/Luhe, Germany and the abundance of microbial resources. Hydrobiologia 440:357-367

Thompson RC, Norton TA, Hawkins SJ (2004) Physical stress and biological control regulate the producer-consumer balance in intertidal biofilms. Ecology 85:1372-1382

Trussell GC, Johnson AS, Rudolph SG, Gilfillan ES (1993) Resistance to dislodgment - habitat and size-specific differences in morphology and tenacity in an intertidal snail. Mar Ecol Prog Ser 100:135-144

Underwood AJ (1984a) Microalgal food and the growth of the intertidal gastropods Nerita atramentosa Reeve and Bembicium nanum (Lamarck) at four heights on a shore. J Exp Mar Biol Ecol 79:277-291

Underwood AJ (1984b) The vertical distribution and seasonal abundance of intertidal microalgae on a rocky shore in New South Wales. J Exp Mar Biol Ecol 78:199-220

Underwood AJ (1997) Experiments in ecology, their logical design and interpretation using analysis of variance. Cambridge University Press, Cambridge

Underwood AJ (1998) Grazing and disturbance: an experimental analysis of patchiness in recovery from a severe storm by the intertidal alga Hormosira banksii on rocky shores in New South Wales. J Exp Mar Biol Ecol 231: 291-306

Wahl M (1989) Marine epibiosis. I. Fouling and antifouling: some basic aspects. Mar Ecol Prog Ser 58:1-2

Submitted: January 19, 2004; Accepted: January 20, 2005

Proofs received from author: May 25, 2005 